\title{
Towards a Different Construction of Blackness: Black Immigrant Scholars on Racial Identity Development in the United States
}

\author{
Kathy-Ann C. Hernandez \\ Eastern University \\ U.S.A. \\ Kayon K. Murray-Johnson \\ Texas State University \\ U.S.A.
}

ABSTRACT: In this collaborative autoethnography, two immigrants interrogate their evolving self-definitions as Black women in the U.S. academy. Using a variety of data sources, they uncover several commonalities and differences in their experiences which have coalesced into a four-part model in their journey towards a different construction of Black identity: positioning themselves in the Black box, apprehending their outsider-within positionalilty, navigating the "us/them" to "we" switch, and integrating a different construction of Blackness while remaining true to their cultural/ethnic identity. In elaborating on these themes, they critique the journey towards apprehending minority identity status for people like them.

KEYWORDS: Black Identity, Women of Color, Immigrant, Intersectionality, collaborative autoethnography

\author{
Overview of the Literature \\ Conceptual Framework \\ Method \\ Findings \\ Towards a Different Construction of Blackness \\ Conclusion \\ Implications for Research and Practice \\ References \\ Author Contact
}

Scholars have contended that the growing presence of immigrant Blacks in the United States suggests the need for more particular analyses of the nuances of Black racial identity (Hall \& Carter, 2006; Perry, 2002). Whereas the United States' construct of race largely defines the "Black experience" for most U.S.-born Blacks, multiple elements (e.g., ethnicity, nationality, race) make up the "Black experience" for many Blacks who are foreign-born (Kretsedemas, 2008; Warner, 2012). Consequently, studies have found that Black immigrants' racial perspectives and experiences are often incongruent with those of their African American counterparts (Alfred, 2010; Fries-Britt, George Mwangi, \& 
Peralta, 2014; Murray-Johnson, 2013; Ogbu, 1993; Okonofua, 2013; Waters, 1999). For example, hooks (2000), writing in the context of women in the African Diaspora, explained that though ethnic groups may be similar, there are no monolithic "Black experiences" (p. 59). This incongruence concerning racial/ethnic worldviews is further complicated by a growing awareness that models of Black identity development appear problematic for foreign-born Blacks. Since these models were developed within the context of a racialized U.S. history and racial construct, they are limited as lenses through which Black immigrants' racial and ethnic identity experiences may be effectively examined.

Much previous research on foreign-born Blacks in the United States has included a focus on their race-related perspectives and experiences (Perry, 2002). However, studies on the issue of process, and by extension models that might frame or undergird the Black immigrant's racial/ethnic identity experience, are few. Rather, in the literature, Black immigrants' perspectives are often subsumed within the larger category of American Blacks. Both U.S.-born and foreign-born Blacks play an integral role in understanding how racial and ethnic identities are formed (Cornell \& Hartman, 2007; Hall \& Carter, 2006; Jackson, 2012). Hence, it is important to explore alternative perspectives to advance more inclusive approaches to defining Black identity, which accurately reflect the diverse U.S. population (De Walt, 2013; Jackson, 2012; Worrell, 2012). Using the experiences of two Black Caribbean immigrants as an example, this study interrogated evolving self-definitions of foreign-born Blacks in the United States. The central research question that guided the study was: How do two foreignborn and socialized Black women come to construct "Blackness" as Caribbean immigrants in the United States?

\section{Overview of the Literature}

The growing presence of Black immigrants in the United States has served both to question and to add critical dimensions concerning what it means to be "Black" (Bailey, 2001; De Walt, 2013; Kretsedemas, 2008; Johnson, 2008; Perry, 2002). Johnson (2008) succinctly illustrated this influence with the use of Hughes' (1945) "master status" - that is, America's longstanding definition of Blackness founded on its racialized past. According to Hughes, Blackness, as defined by U.S. standards/norms, tends to override other demographic characteristics, but Black immigrants have "contributed to...the creation of ethnic groups within a racialized American ethnicity, thus shattering the erroneous, even if enduring, notion of a monolithic Black America" (p.77).

Given this, researchers have argued that essentialized meanings of Blackness and discourses on race in general are being challenged and transformed (Alfred, 2010; Benson, 2006; Brooks \& Clunis, 2007; Kretsedemas, 2008; Warner, 2012). Since racial identity is complex and problematized by factors such as unique ethnic and cultural experiences outside the U.S. context, there is need for (a) a broadened racial discourse shaped by ethnic group identity 
and affiliations (Alfred, 2008, 2010; Fries-Britt et al., 2014; Hall \& Carter, 2006; Benson, 2006), and (b) models that centralize the unique ideologies of foreignborn Blacks (De Walt, 2013; Wilson, 2009).

\section{Black Identity Development Models}

Models of Black identity development in the United States arose from the Civil Rights era as psychological frameworks within which a Black individual's racial "self" might be examined. Among those most cited or "mainstream" are Cross's $(1971,1995)$ "Nigrescence" models, Helms' (1984) People of Color model, and Jackson's $(1975,2012)$ Black Identity Development models. In Cross's models, Blacks experience identity development through pre-encounter, encounter, immersion-emersion, internalization, and internalization-commitment stages, a movement ranging from favoring White American culture to experiencing a "personal sense of Blackness" (Tatum, 1992, p.12). Helms subsequently modified Cross's (1971) model by suggesting each stage be considered a status or worldview, a more subjective and fluid view of identity development (Richardson, Bethea, Hayling, \& Williams-Taylor, 2010).

Like Cross (1971), Jackson's (1975) model of Black identity development involved conforming to White norms as the first stage. Beyond this passive acceptance, Blacks undergo active resistant, redefinition, and internalization stages: from anger towards White society to development of African American values, "diminished anger towards Whites," and cultural pride (Jackson, 2012, p.45). Jackson later revisited his model and broadened internalization, given such influences as globalization, immigration, and Crenshaw's (1991) intersectionality theory.

However, these major theories of Black identity development highlight a few of the challenges with existent models. First, though useful in explicating the construction of Blackness for African Americans, they are often poor fits for the construction of Blackness among foreign-born Black immigrants (Hernandez, Ngunjiri, \& Chang, 2014). Second, such models have not been malleable enough to acknowledge contemporary globalism, immigration, and theoretical influence and, in particular, the role of culture or ethnicity in identity formation (Constantine, Richardson, Benjamin, \& Wilson, 1998; Fries-Britt et al., 2014; Hernandez, Ngunjiri, \& Chang, 2014; Richardson et al., 2010). For example, the investigation by Fries-Britt et al. (2014) of how foreign-born students of color made meaning of racialization in the United States found that no one model of racial identity development fully captured the nuances of these students' experiences. They concluded that "greater theoretical work on racial-ethnic identity development [is needed].... Future research should consider other aspects of foreign born students' racial-ethnic identity that traditional models created to examine identities of U.S. born people of color do not address" (Fries-Britt et al., 2014, p.11). Hence, ongoing modification of theoretical models is necessary "to 
accommodate increasingly global perspectives and experiences" if such models are to be relevant and useful (Jackson, 2012, p. 35).

\section{Conceptual Framework}

To make sense of our experiences as foreign-born Black women in the academy, we relied on two broad conceptual frameworks: intersectionality and post-colonial narratives. As Crenshaw $(1989,1991)$ has noted, Black women experience tensions at the intersection of a combination of their various socioidentities, in this case our Black and immigrant identities. Anzaldúa (1992) captures well the tensions of this intersectional space as being in a constant state of mental nepantilism, an Aztec word meaning "torn between ways."

As foreign-born immigrants, from Trinidad/Tobago and Jamaica respectively, we have migrated from countries where we were members of an ethnic majority group. Suddenly placed in the U.S. context, we occupy an intersectional space of being both outsiders and insiders to an often essentialized Black experience. Our experiences as both majority and minority members allow us a unique vantage point for constructing this new Black identity. Ironically, however, it is this dual status that creates the most personal and social challenges for us in understanding our emerging identity and how it affects our relationships with both Blacks and Whites.

Additionally, post-colonial studies, as a framework for this study, serve to interrupt commonly held assumptions and views regarding race and racism. By adding the voices of indigenous and colonized groups, it "tries to understand how individuals and group identities are constructed... often in quite contradictory ways" (Tikly, 1999, p. 611). The post-colonial framework is particularly relevant to this study since (a) it emphasizes that groups are not monolithic and that ethnicities are varied and complex; (b) its scholars bring a specific interest in race and the Diaspora to the fore, coupled with a direct challenge to the ways that identity has typically been "coded" (English, 2005); and (c) it suggests the notion of a "third space" (Khan, 1998, 2000) where identities are constructed, reconstructed, and negotiated in the face of ambiguity (English, 2005). Thus, borrowing from the work of Anzaldúa (1992), we celebrate the idea of this liminal third space with the understanding that "at some point, on our way to a new consciousness, we will have to leave the opposite bank, the split between the two mortal combatants somehow healed so that we are on both shores at once" (p. 388).

\section{Method}

We employed autoethnographic methods in this study. Autoethnography can be defined as the study of self in relation to others within a particular social 
setting (Chang, 2008; Ellis, 2004). Some autoethnographers focus their work more on self, while others adopt a more analytical stance focused on the cultural interpretation of events involving self (Chang, 2008; Reed-Danahay, 1997). In this work, we lean more towards the analytical end of the continuum.

We used a variety of data collection strategies in three phases. In Phase 1 , we independently completed a culturegram, a visual organizer for mapping out one's primary identities (Chang, 2008) and independently wrote critical incidents in which we were made to confront skin color and its implications in our country of origin and then here in the United States. In Phase 2, we reviewed each other's writings and narrowed the focus of the study around six follow-up questions. In Phase 3, we met in two rounds of one hour interviews relevant to these questions.

Table 1 shows that our research method is consistent with the four areas of establishing credibility in autoethnographic work as outlined by Hughes, Pennington, and Makris (2012).

Table 1

Manuscript Adherence to AERA Standards: Autoethnographic Evaluative Checklist

\begin{tabular}{|l|l|}
\hline \multicolumn{1}{|c|}{ Focus Area as per AERA } & \multicolumn{1}{c|}{ Study Characteristics } \\
\hline $\begin{array}{l}\text { Formulating social scientific } \\
\text { problems } \\
\text { (2006 AERA Standards 1, 2) }\end{array}$ & $\begin{array}{l}\text { Research problem anchored in the observations } \\
\text { of others (Alfred, 2008, 2010; Edmonson, 2006; } \\
\text { Fries-Britt, George Mwangi, \& Peralta, 2014; } \\
\text { Hooks, 2000). } \\
\text { Method-transparent method based on } \\
\text { adherence to guidelines for CAE (Chang, } \\
\text { Ngunjiri, \& Hernandez, 2013). }\end{array}$ \\
\hline $\begin{array}{l}\text { Critical, careful and thoughtful } \\
\text { discussion of methods } \\
\text { (2006 AERA Standards 2, 3, 6 }\end{array}$ & $\begin{array}{l}\text { Method: Detailed description of Study Phases } \\
\text { and design logic as consistent with tenets of an } \\
\text { analytic approach to autoethnographic work } \\
\text { (Chang, 2008; Reed-Danahay, 1997). }\end{array}$ \\
$\begin{array}{l}\text { Discussion of the limitations posed to the study } \\
\text { findings based on CAE method (see discussion } \\
\text { section). }\end{array}$ \\
\hline $\begin{array}{l}\text { Multiple levels of critique, naming } \\
\text { and classifications; and criteria for } \\
\text { selected units and classifications. } \\
\text { (2006 AERA Standards: 3, 4, 5) }\end{array}$ & $\begin{array}{l}\text { Analysis: Multiple units of analysis employed in } \\
\text { the study: self (culturegram) (Chang, 2008); self } \\
\text { in relation to cultural group episodes } \\
\text { (independent writing of critical incidents) with a } \\
\text { discussion of how data were collected. }\end{array}$ \\
\hline $\begin{array}{l}\text { Multiple Levels of Critique: Employed a full- } \\
\text { concurrent coloration model with independent }\end{array}$ \\
\hline
\end{tabular}




\begin{tabular}{|l|l|}
\hline & $\begin{array}{l}\text { Writing, focus group sessions; dyadic reviews } \\
\text { and critiques of recollections and writings } \\
\text { (Ngunjiri, Hernandez, \& Chang, 2010). }\end{array}$ \\
\hline $\begin{array}{l}\text { Credible analysis and interpretation } \\
\text { of the evidence from narratives and } \\
\text { connecting them to researcher-self } \\
\text { via triangulation member-checks } \\
\text { and related ethical issues }\end{array}$ & $\begin{array}{l}\text { Connection to the literature: Findings are } \\
\text { connected to works of other immigrants on this } \\
\text { topic (Alfred, 2008, 2010; Fries-Britt, George } \\
\text { Mwangi \& Peralta, 2014; Johnson, 2008; } \\
\text { Waters, 1999). }\end{array}$ \\
& $\begin{array}{l}\text { Ethical Issues: Authors use of pseudonyms, } \\
\text { amalgams, and permission seeking from co- } \\
\text { authors and other individuals implicated in the } \\
\text { CAE before public dissemination (Ellis, 2004; } \\
\text { Hernandez \& Ngunjiri, 2013). }\end{array}$ \\
\hline
\end{tabular}

We both participated in co-analyzing the data at two levels: independently and collaboratively. After Phase 1 of data collection was completed, we exchanged culturegrams and independent writing for review. After the Phase 3 interviews, we both participated in transcribing sections of the interview, recognizing transcription as a preliminary step in the analysis process. The transcripts were then individually read and re-read, consistent with Agar's (1980) recommendation of immersion in the data (p. 103). In reading, we independently compared interview data with our written documents to code meaningful ideas. These codes were re-examined across the two transcripts and written documents. Overlapping and redundant codes were collapsed into broad themes with supporting text segments relevant to our research question. We later met in a data analysis session to discuss and negotiate our themes.

\section{Findings}

In the following sections, we first situate ourselves as Black immigrants in U.S. society by telling our stories. We then elaborate on these themes while critiquing the journey towards our new construction of Blackness and in finding a space to talk openly about our experiences.

\section{Our Stories}

Kathy-Ann. I was born in the twin island Republic of Trinidad and Tobago and grew up there for most of my life. I migrated to the United States in August 2000 to pursue doctoral studies at Temple University. I grew up in an atypical household, raised by a single-parent father after my mother had packed up one morning (I am told) and left us, never to return. As a result, I spent a lot of time with my paternal grandmother when my father went to work. My father's side of 
the family was of "Spanish" descent and very light-skinned. My mother's side of the family was very dark-skinned and of strong African descent.

Growing up under my grandmother's care, I would often hear my mother referenced as that "'ole' good for nothing Black woman." Though I am not sure how much of that description was entangled with her actions, I came to associate Blackness with "less than," "not as good as." To my mind, beauty was inextricably tied to color of skin. Additionally, because of my mixed parentage, and for that part the mixed parentage of mostly everyone else in my community, I was aware of a certain kind of shade prejudice. As I think of these confrontations with skin color though, it is clear to me that it did not move beyond mere aesthetics. For some reason, we had been socialized to believe that White/light skinned was more beautiful. However, as I grew up, I did not at all feel the weight of these color issues. My skin color was as natural to me as the color of my hair, and in a lot of ways I was very proud of it as a unique mixture of different races that spoke to the cosmopolitan nature of the Trinidadian experience. I was "Trini": that was just it.

Kayon: Growing up in Jamaica, I lived with my mother, but my father was also an active participant in raising me. Both my parents were working class citizens, and both were influential in the way I came to understand my "racioethnic" self, as well as issues of race in a Jamaican context - albeit in different ways.

I was Daddy's only child, and he constantly reminded me of his straight "Irish" nose which I inherited (at the time, such a physical feature felt like a gift from the gods). Mommy was very dark-skinned and had a beautiful broad nose mimicking female features I have seen in pictures from some villages in African nations. She often told me stories about her own childhood during which she frequently heard that she was just "too Black" and that Blackness was never anything that could be "the best." Yet she always encouraged me to aim high. Time spent with my father also involved an encouragement to aim high but often came along with repetitive stories about his carefully selected friends, who were the "better friends" to have in life. Several were lighter-skinned. Most appeared to be middle class or above.

Though I harbored a few questions about self and identity, I did notice that many Black Jamaicans were highly educated and, subsequently, successful in social circles. This was an area that I felt I had an equal shot at because it was highlighted as the quintessential value of my family and community. My mother always emphasized the importance of education and hard work as the key to success. Because of this, I felt very comfortable in my own skin and really cannot remember a time when I ever wanted to be anything but as dark as I am.

\section{Towards a Different Construction of Blackness}

Figure 1 shows a visual model of our experiences in reconstructing our 
Black identity in the United States relevant to four emergent themes: (a)

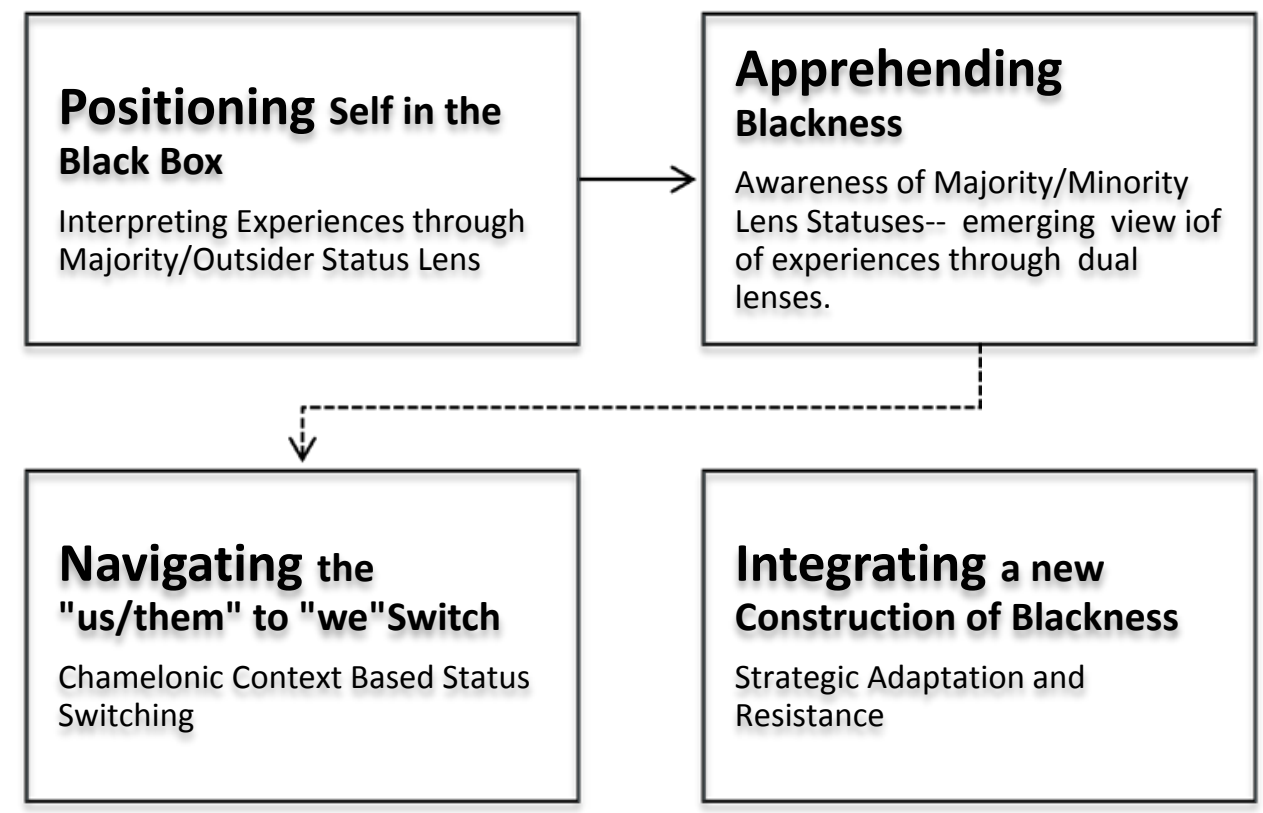

Figure 1. Towards a new construction of blackness

(Note: Dotted line indicates length of time in the United States).

positioning ourselves in the Black box; (b) apprehending our outsider-within positionalilty; (c) navigating the "us/them" to "we" transition; and (d) remaining true to our cultural/ethnic identity. We categorize the first two themes as having occurred early in our U.S. immigrant experience. The latter two are current and continuous strategies influenced by our length of stay in the United States.

\section{Positioning Ourselves in the Black Box}

We both encountered challenges in understanding how to position ourselves as Caribbean-born Black women in this new space. First, we extrapolated similarities between our early understandings of Blackness in Caribbean contexts and then juxtaposed these with our emerging understanding of the positions we now occupy in this context. Blackness in our early socialization experiences was recognized as aesthetically inferior to Whiteness. As residuals of slavery in Caribbean contexts, this notion was also tied to social class since those in positions of power had retained and passed on wealth to their descendants. However, as others (e.g., Shapiro, Sewell, \& DuCette, 1995) have observed, though race and social class were sometimes entangled as factors at the basis of social standing, social class was the more potent force. In reflecting on her early experience, Kathy-Ann notes the following:

[A]s I sought to make my place in Trinidad society, the only really handicap I saw to making it was based on having access to resources. I understood that I would have to work very hard to climb the social ladder. 
This was true of anyone light-skinned or dark-skinned-hard work was the key to social mobility.

However, in the U.S. context, we became aware of the intersection of race and class and the negative implications for people of color. As high achievers, we each experienced instances of shock by White superiors, professors, and colleagues alike that we could be both Black and "articulate" or good writers. Kathy-Ann recalls one of her former bosses complimenting her by saying, "You write very well for someone from the Caribbean." Implicit in that backhanded compliment was the expectation that perhaps Black people like her from the Caribbean were not expected to write well. Similarly, Kayon recollected that in graduate school, she was referred to by a White female, as "the standout...intelligent Black student from the Islands."

Early experiences in the United States context made it clear to us that our Black lenses had been fashioned by different circumstances than our African American counterparts and continued to be lenses from which we interpreted our experiences. Coming from cultures in which we were members of the majority group, we instinctively came to this context with a majority status lens. Yet, on the basis of our skin color, we have found ourselves positioned alongside our African American counterparts, who, based on U.S. culture, occupy "minority" status. The challenge that confronted us in positioning ourselves in this space was how to hold on to our cultural and sociopolitical identities respectively, without feeling compelled to side with an African American cause because we were Black. As Kayon notes, in this racialized space,

If we have a room and there are African Americans on the left and Indians on the right, I feel like I have a political duty to shift over to the left because as long as there is a cause to be fought for African Americans within the academy or in a social group-then I MUST side with that because they are Black.

Hence, migration to the United States has positioned us in a dichotomous situation. We both described struggling with (a) the concept of the either/orWhite or Black-dichotomy and (b) the reality of this racialized U.S. space and the subsequent essentialized Black status-the Black box. We define the Black box as the normative classification of individuals based on Black skin color as the dominant socio-identity marker in U.S. society. For example, our primary identifier in public and professional spaces when we arrived in the United States was based on our nationality. Kathy-Ann still identified as a Trinidadian and Kayon identified as a Jamaican. Kathy-Ann observed:

When I identify myself by putting my nationality first, it is a political choice. So in this context, to put race or skin color at the forefront when I define myself is to give importance to that when I don't necessarily subscribe to the view that that is what is important about me.

We still viewed our nationality as our dominant identity marker rather than our skin color. As such, our initial positionality in this space was categorized by a sense of "us," Caribbean nationals, as different from "them," African Americans. 
Yet, in this space we described instances of feeling "Blackness" thrust upon us as the most salient identity marker. For example, Kayon recollected being chastised by another African American student in one classroom encounter in which she was trying to articulate distinctions in her Black self-identity as a Jamaican woman relevant to African American women. The criticism was that there was no distinction-either you were Black or White. In our discussions, she lamented that, even though her "gut response" was to maintain her position, she acquiesced because she realized that, in this given context, "once you get here you assume that identity-almost like an essentialism-you are just stuck in the box of Black - there is not necessarily a gradient or shades of gray."

Similarly, Kathy-Ann described some of the angst she felt from other native-born Black women when self-defining in personal and professional contexts. For example, because she has kept her paternal last name, people are often puzzled by her appearance when they meet her. Some have even said openly: "But you are not Hispanic." To which she would often respond: "Yes, I am." She does not self-define as African American, although she is married to African American man and has two African American daughters. She has rationalized this distinction as follows:

As the product of a mother of African Caribbean descent and a father of Hispanic ancestry, I see this not as a denial of my Blackness but an affirmation of my own heritage - an act of homage.... Identification with the country of my birth and my father's heritage are salient, as I was raised in that context, by my single-parent father and my paternal grandmother. Why then should I be forced to divest my own heritage to occupy this space? I do recognize that I am in the process of adapting to this new home--but I am not there yet. I do not fully own the experience of being an African American, and I cannot take that label unless it fits me well. (Hernandez, Ngunjiri, \& Chang, 2014, p. 6)

In light of this, we were faced with daunting questions: How do we find our space alongside our Black sisters and brothers and negotiate our dubious inheritance of disenfranchisements and marginalization? Additionally, how do we navigate relationships with members of the White majority - whose positions we once occupied in our respective home contexts? Our early experiences in the US were characterized by this positioning/repositioning of ourselves in a Black box, set against the backdrop of a racialized United States context.

\section{Apprehending Blackness}

As Black Caribbean immigrants in academe, we recognized the emergence of dual lenses for interpreting our experiences. Our majority lens perspective birthed in our socialization in our home countries is bifurcating into a minority-lens perspective the longer we are in the United States. Thus, we are learning to constantly co-exist between these two spaces as well as acknowledge the intersectional tension as a third space in our construction of Blackness. In this way, Blackness for us becomes a constant and complex 
identity.

The complex nature of our dual Black identity is not only a by-product of our ties to the Caribbean and to the United States, but it is also greatly enhanced by the divergent assumptions made about us and expectations placed upon us by White and African American groups. For example, our collaborative work revealed that some Whites tend to affix a more positive stereotype to us than they do to Black Americans. Kathy-Ann recounted an experience with a former professor who lamented what he saw, while driving through their communities, as negative attitudes and a way of life displayed by some African American cultures. In reference to her, at the end of his statement, he noted, "but you are not like them." This implied a sort of positioning of her as a Caribbean Black immigrant as separate from U.S.-born Blacks. Kayon concurred, citing her own experience with a White colleague who confessed during a discussion on race and culture that

[I]t is so sad I have to tell you the truth...that many of us like to talk to you more than we like to talk to African Americans because there is something different about Caribbean people and how they see themselves as being black.

Experiences like these were troubling. As Kathy-Ann observed after the above encounter, "Inside I was conflicted. I felt happy that he did not include me in the group of 'these people.' Yet at the same time, I was disturbed by his characterizations of people who looked just like I did" (Hernandez, Ngunjiri, \& Chang, 2014, p. 8).

As added components to the complexity of our dual lenses, we have also struggled with having to defend the existence of our dual lenses and our reticence to define as African Americans. "But you are Black," we are often told. Though we concur with this, we also acknowledge our identity formation as shaped primarily by our respective homelands. Kathy-Ann's response to questions of how she chooses to identify provides an accurate synopsis of how we interpret, rationalize, and articulate our self-definitions as foreign-born Black women. She contends, "Yes [I am Black], but it does not mean the same thing for me as it does for you."

Apprehending Blackness in our context means we can neither deny the primary identity rooted in our Caribbean upbringing, nor deny the relevance of racializing our identities in context, given the realities of America's past and present. Kayon illuminates the duality we embody:

I had to adjust my identity, almost make it fluid - I had to be conscious of the fact that I was in a space where to be Black, you were really at the lower end of the spectrum-so I had to consciously do that-so yes I am Jamaican-but I am a Jamaican in the context of this space-and that is largely how I self-define-but at the same time I have to self-identify as a Black person in the United States and all the issues that come with that and all of the potential issues that could come without that. 
As fluidity and dual identities characterize our apprehension of Blackness, we have found that our earlier constructions of Blackness in a Caribbean context have been expanded in order to become inclusive of contexts that are far more explicitly racialized than we had previously encountered. This duality positions us uniquely in an intersectional space, as outsiders/within, simultaneously occupying majority and minority statuses.

\section{Navigating the "Us/Them" to "We" Switch}

We regard our process as an identity journey that is continuing. The path to this new construction of Blackness involves learning how to link our pre-U.S. Black self-definitions with our emerging self-definitions. Linking these two aspects of our identities involves a back-and-forth movement from our initial positionality of the "us/them" to the "we" mentality (i.e., all Blacks in the United States subsumed under one racial identity group). We have found reconstructing and deconstructing inherent in this switch to be challenging because it involves an ongoing interrogation of who we are in this more distinctly racialized space.

In the first instance, we experience much apprehension to even talk about our transnational struggles in social and academic spaces because our statuses color our perspectives and inform the language we use in explicating this process of moving towards a different construction of Blackness. For example, we have been told that our perspective is colored perhaps by a "White way of knowing" or that we think "we are better than African Americans." Kayon recalls presenting at a conference where she received strong pushback from a few members of the audience against her postionality of "us" versus "them." She recollected that one participant said angrily: "You keep using the term 'them,' and as long as you keep calling it them, we will never get anywhere!" In yet another encounter, Kayon was cautioned against being too detailed with her experiences and subsequently "jeopardizing" relationships that had been formed with African American peers. Hence, even at the time of initiating this research project, we were constantly conscious of using the "right" language, so as not to offend.

Secondly, because our navigation between these levels of identification is dynamic, there are inherent ongoing navigational tensions. Kathy-Ann describes her experience with the back-and-forth tensions involved as follows:

Sometimes I make jokes with my husband and say: "That is how you Americans are?" It is not meant to be cruel. You see, I still identify with my country of origin, because I do not see myself as fully African American. Any yet, it is very complex, because in some sense I also identify with him and his experiences, and I want to identify with the experiences of my daughters. But I still feel apart from them.

In a similar way, given the two spaces she calls home, Kayon raises key questions at the intersection of her identity as a Jamaican national and the racial identity she is now in the process of assuming: 
I cannot say I've found a [set] community... it's between these things - who I know myself to be as a Jamaican, and making this necessary alliance is what I'm processing. I mean, I refuse to be "boxed." But I notice that I say much less that I am from Jamaica... I no longer say that as the first thing, and that is interesting to me.

Hence, our navigation between "us/them" to "we" is characterized by a chameleonic way of being and knowing, a non-fixed identity movement that does not necessarily reside on either side of the continuum. Kathy-Ann describes it as not seeing ourselves as "either/or" but as "both/and" (Hernandez, Ngunjiri, \& Chang, 2014, p. 6).

In spite of these tensions, we recognized that, as scholars with research agendas focused on the Black Diaspora, we are challenging ourselves to reflect on and make sense of our journey. This involves contrasting earlier and more recent perceptions about issues affecting African American. As Kathy-Ann shared,

I remember distinctly when I first came to the United States at the University...I was becoming aware of some of the issues among African Americans... and I remember still thinking to myself I don't understand why are they so-why are THEY this way-why can't they just work hardbecause that is how we were raised.... But now after being here and experiencing things-I see why that principle does not work the same way here as it does for us in the Caribbean because there are such structural inequities that are systemic and so-I think of it differently now.

We recognize that in this space which we now call home, our Blackness comes with a self-imposed Black identity agenda. This agenda demands a reconstruction of our primary identity into a more inclusive Black identity structure given the painful realities of historical and present-day systematic racial inequities. It necessitates clarity about our social justice agenda relevant to our collective experiences (foreign-born and U.S.-born) as Blacks in the United States. In spite of the tensions in examining our divergent and convergent experiences around Black identity issues, it demands the courage, as Kathy-Ann contends, "to open up spaces within the academy for people to talk honestly and openly about these issues."

\section{Integrating our New Construction of Blackness}

The evolution of a new construction of Blackness involves an intricate process of adaptation and resistance. We recognized in our deliberations that we are both at different stages in the process of integrating our socialized constructs of Black identity with our inherited identity in U.S. society. A salient contributor in this evolutionary journey is our length of stay in the United States and the ensuing personal and professional experiences in this context.

For example, Kathy-Ann explained that she understands the necessity of adaptation that is tempered by controlled resistance. Being married to an African 
American male and having two African American daughters ties her to the reality that she is a Black woman in the United States and to the nuanced understanding of what that means. This understanding of her new Black identity creates moments of stress. She recalled a critical incident in her recognition of this integration which occurred one day as she was dropping her daughter off at a predominantly White daycare center. Having forgotten the new passcode to open the door, she waited until another White parent approached and simply walked in after her. Suddenly, the parent turned around, glared at her, and said sharply, "Close the door behind you!" Kathy-Ann recalls: "I sensed an air of suspicion in the way she looked at me... as if I were about to come in there with an Uzi-while I appreciated her concern about security—I felt she could have engaged me differently." As Kathy-Ann analyzed her feelings around the incident, it was clear to her that she was no longer viewing the experience from her early understanding of herself and her cultural/ethnic Black identity. She described the emergence of an alternate understanding this way:

Previously I would just interpret that as: "This is a rude person." Now because of my experiences with my husband and my own experiences living in certain neighborhoods, and my daughters attending predominantly White schools, I now have all of these filters.... So I begin to think, "You know what, a lot of this has to do with the fact that I AM Black." And I am not sure-I may never be sure. But that becomes a part of analysis. So, I begin to think of myself as a Black woman because I begin to see myself through their eyes.

As she observes, her cultural/ethnic Black lens is now being integrated with a new lens based on her Black experiences in the United States.

In Kayon's experience, she has also adapted filters regarding the way in which she views such critical incidents. As she explained, "[Now] I am very conscious of the colors in the room...very very conscious of the colors in the room." Still, these filters leave her with a gnawing question as she integrates a new, and evolving, construction of Blackness, particularly in cases where there is no explicitly displayed discrimination: "How do I know [for sure] that this person [of a dominant culture] is marginalizing me?"

Paradoxically, coupled with this adaptation, is resistance. Part of that resistance is also birthed in the understanding that the construct of Blackness is in itself evolving in the U.S. sociopolitical context and will continue to do so for our children. Kathy-Ann reflected on the fact that her daughters have been born in the era of America's first African American president. The similarity between their outlook and hers thus appears striking, as in her home country the person who occupied the highest office was always a person of color. This is in stark contrast to the experiences of her husband. However, Kathy-Ann believes that "we are on the cusp of treading new frontiers and to experience the shifting of old boundaries or archaic ways of thinking." Yet another element of her resistance involves passing on the legacy of her birth to her daughters, so that as partAmerican and part-Trinidadian, they can enter into the experience of being both 
outsiders and insiders to the Black experience in the United States and benefit from their inherited legacy as occupants of both majority and minority statuses:

I don't want my children to inherit the perspective of being given an outside label; I want them to be able to self-define because of their Trinidadian and American heritage, and I would like to think that their identity formation is influenced not just by their social context but by what I bring to the table as someone coming from a majority culture.

In addition, we also resist because we choose to focus on the strengths of our experiences as Black immigrants from the Caribbean and our socialization. This colors how we present ourselves in this context. Kayon summarized it this way:

What you see is boldness and confidence; it is a work ethic that is embedded and ingrained. You made a decision to migrate so you come in knowing that you have no money so it is almost like a mindset where you are ready to go and there is nothing that can stop you once your foot is in the door.

That is the rich legacy that we think is worth preserving. Indeed, this ability to bring dual lenses to bear on our experiences as foreign-born women of color positions us at a unique vantage point.

While Kathy-Ann is further along on the journey, Kayon reflected on her positioning as a "very fluid" and "contextual" space. Collectively, even though we are at different points in our journey, we both recognized that in the process of integrating this new construction of Blackness through the process of adaptation and resistance, we are developing strategies to survive and thrive in this evolving identity structure. Among our Caribbean peers in personal and professional spaces, we remain Trinidadian and Jamaican respectively, as advocates to give voice to our unique experiences as foreign-born Blacks. At the same time, in the academy, we also identify with the larger category of women of color and with the need to give voice to their experiences as part of our scholarship. As Kathy-Ann noted:

I still see myself as a Trinidadian and in some respect as an immigrant living in the US. However, in the academy I see myself as a woman of color because of the experiences I have with women who look like me. And yet I still feel apart from them.... For example, I kept my last name after marriage....because I really wanted to honor my father and his heritage....but the more I think about it, the more it MEANS to me that this is who I am. It is more than just a name. It has a lot of implications and it brings back memories of home and growing up with my father. So in a nutshell I still see myself BOTH as "us/them" and "we."

Similarly, Kayon expressed it this way:

I understand that I am situated in a racially normalized USA and that even though I consider myself to be a strong confident Jamaican woman, I have to adjust my identity almost make it fluid.... So now, I self-define as 
Jamaican based on my cultural values, the values of my faith in Jamaica and my family - but at the same time I have to self-identify as a Black person in the United States and all the issues that come with that.

In choosing to recognize and own our new construction of Blackness, we are empowered to give voice to our experiences and advance scholarship pertinent to these issues.

\section{Conclusion}

The model that has emerged from this collaborative interrogation of our Black identities is unique to our perspectives and lived experiences as Caribbean immigrants. It also reflects a complex lemniscating between identities. Consistent with the findings of other scholars (e.g., Alfred \& Swaminathan, 2004; Fries-Britt, et al., 2014; Hall \& Carter, 2006; Kretsedemas, 2008; Richardson et al., 2010; Wilson, 2009), this complexity resides in the fluid and dual nature of our statuses as Blacks originally socialized in a majority culture who are also being resocialized as minorities in a U.S. context.

In keeping with a post-colonial frame (Tikly, 1999), our findings underscore that factors (in our case, ethnicity and cultural norms), rooted in each of our country's sociopolitical histories, have emerged as more salient for us than race as it is understood in the U.S. context. Much of our Black identity construction then remains a space of tension, congruent with Crenshaw's (1991) theory of intersectionality. As Anzaldúa (1992) explained, "The ambivalence from a clash of voices results in mental and emotional states of perplexity" ( $p$. 387). Yet, we reject the notion of this intersectional space as a limitation. Instead, we embrace the fluidity and duality of our lenses as a conscious way of knowing. Instead of viewing them as places from which we must make a fixed choice between one "Black" identity and another, we are choosing to view them as complementary worldviews. As scholars in higher education, we echo the call for an embrace of a hybrid consciousness and "a tolerance for ambiguity" (Anzaldúa, 1992, p. 388) that can move the discourse on racial constructs and diversity forward in authentic ways.

\section{Implications for Research and Practice}

Our findings suggest that additional studies are needed on Black immigrants from diverse territories that will analyze salient factors contributing to their racial identity development processes. As Wilson (2009) observed, "There is something about each group's history, language, and experience that provides for us a particular perspective" (p.203); focusing on individual position is critical since it shifts the attention from race as the salient factor (Fries-Britt et al., 2014). For example, researchers might probe how class, gender, and/or religion might 
intersect with race and impact Black identity for some within a racialized U.S. context. By extension, they might also investigate how foreign-born Black identities might impact pedagogical or administrative practices in the academy. Such empirical investigations might stimulate (a) a "re-working" of identity labels that Black immigrants on varied campuses have found "problematic" and noninclusive such as "other" (De Walt, 2013); (b) a more accurate depiction of racebased categories in research practice; and (c) professional development and training practices in the academy that are truly culturally responsive for both foreign-born faculty and students.

Given these observations, we acknowledge this model as a work in progress, but a critical step in further opening up honest discourse in the academy. By including our foreign-born contexts, it directly addresses the gap in the literature that speaks to Black identity models; moreover, it provides an additional platform for a very necessary expansion of the discourse on race and ethnicity in the face of an increasing immigrant U.S. population.

\section{References}

Agar, M. H. (1980). The professional stranger: An informal introduction to ethnography. San Diego, CA: Academic Press.

Alfred, M. (2008). Breaking the silence and expanding the discourse: Racioethnic identity and perceptions of race among people of the African Diaspora. Proceedings of the $49^{\text {th }}$ Annual Adult Education Research Conference. St. Louis, MO: University of Missouri - St. Louis.

Alfred, M.V (2010). Challenging racism through postcolonial discourse: A critical approach to adult education pedagogy. In V. Sheared et al. (Eds.), The handbook of race and adult education: A resource for dialogue on racism. San Francisco, CA: Jossey-Bass.

Alfred, M., \& Swaminathan, R. (2004). Immigrant women of the academy: Negotiating boundaries, crossing borders in higher education. New York, NY: Nova Science Publishers.

Anzaldúa, G. B. (1992). La conciencia de la mestizai: Towards a New Consciousness. In G. Colombo, R. Cullen \& B. Lisle (Eds.), Rereading America: Cultural contexts for critical thinking and writing ( $2^{\text {nd }}$ ed.) (pp. 286-395). New York, NY: Bedford/St. Martin's Press.

Bailey, B. (2001). Dominican-American ethnic/racial identities and United States social categories. International Migration Review, 35(3), 677-708.

Benson, J. (2006). Exploring the racial identities of Black immigrants in the United States. Sociological Forum, 21(2), 219-247.

Brooks, A. K., \& Clunis, T. (2007). Where to now? Race and ethnicity in workplace learning and development research: 1980-2005. Human 
Resource Development Quarterly, 18(2), 229-251.

Chang, H. (2008). Autoethnography as method. Walnut Creek, CA: Left Coast Press, Inc.

Chang, H., Ngunjiri, F. W., \& Hernandez, K.C. (2013). Collaborative autoethnography. Walnut Creek, CA: Left Coast Press.

Constantine, M. G., Richardson, T. Q., Benjamin, E. M., \& Wilson, J. W. (1998). An overview of Black racial identity theories: Limitations and considerations for future theoretical conceptualizations. Applied and Preventive Psychology, 7(2), 95-99.

Cornell, S. E., \& Hartmann, D. (2007). Ethnicity and race: Making identities in a changing world. Newbury Park, CA: Pine Forge Press.

Cross Jr, W. E. (1971). The Negro-to-Black conversion experience: Toward a psychology of Black liberation. Black World, 20, 13-27.

Cross Jr, W. E. (1995). The psychology of nigrescence: Revising the Cross model. In J. Ponterotto, J. Casas, J. Manuel, L. Suzuki, C. Alexander (Eds.), Handbook of multicultural counseling (pp. 93-122). Thousand Oaks, CA: Sage.

Crenshaw, K. (1989). Demarginalizing the intersection of race and sex: A Black feminist critique of antidiscrimination doctrine, feminist theory and antiracist politics. The University of Chicago Legal Forum, 140, 139-67.

Crenshaw, K. (1991). Mapping the margins: Intersectionality, identity politics and violence against women of color. Stanford Law Review, 43, 1241-99.

De Walt, P. S. (2013). Discourse on African American/Black identity: Engaging the expanded nigrescence theory with a diasporic consciousness. SpringerPlus, 2(1), 233.

Ellis, C. (2004). The ethnographic I: A methodological novel about autoethnography. Walnut Creek, CA: AltaMira.

Fries-Britt, S. L., George Mwangi, C. A., \& Peralta, A. (2014). Learning race in a U.S. context: An emergent framework on the perceptions of race among foreign-born students of color. Journal of Diversity in Higher Education 7(1), 1-13.

Hall, S. P., \& Carter, R. T. (2006). The relationship between racial identity, ethnic identity, and perceptions of racial discrimination in an Afro-Caribbean descent sample. Journal of Black Psychology, 32(2), 155-175.

Helms, J. E. (1984). Toward a theoretical explanation of the effects of race on counseling: A Black and White model. The Counseling Psychologist, 12(4), 153-165.

Hernandez, K. C., \& Ngunjiri, F. W. (2013). Relationships and communities, In T. Adams, C. Ellis, \& S. Holman-Jones (Eds.) (Chapter 11). Handbook of Autoethnography,_Walnut Creek, CA: Left Coast Press. 
Hernandez, K. C., Ngunjiri, F. W., \& Chang, H. (2014). Exploiting the margins in higher education: A collaborative autoethnography of three foreign-born female faculty of color. International Journal of Qualitative Studies in Education, 1-19. doi: 10.1080/09518398.2014.933910 (online first)

Hughes, E. C. (1945). Dilemmas and contradictions of status. American Journal of Sociology, 50, 353-359.

Hughes, S., Pennington, J. L., \& Makris, S. (2012). Translating autoethnography across the AERA standards: Toward understanding autoethnographic scholarship as empirical research. Educational Researcher, 41(6), 209219.

hooks, B. (2000). Feminist theory: From margin to center. Cambridge, MA: South End Press.

Jackson, B. (1975). Black identity development. Journal of Educational Diversity, 2, 19-25.

Jackson, B. W. (2012). Black identity development: Influences of culture and social oppression. In C. Wijeyesinghe \& B. W Jackson III (Eds.), New perspectives on racial identity development: Integrating emerging frameworks $\left(2^{\text {nd }}\right.$ ed.). (pp. 33-50). New York, NY: New York University Press.

Johnson, V. M. S (2008). What, then, is the African American? African and AfroCaribbean identities in Black America. Journal of American Ethnic History, 28(1), 77-103.

Kretsedemas, P. (2008). Redefining 'race' in North America. Current Sociology, 56(6), 826-844.

Murray-Johnson, K. K. (2013). Cultural (de)coding and racial identity among women of the African Diaspora in U.S. adult higher education. Adult Learning, 24(2), 55-62.

Ngunjiri, F. W., Hernandez, K. C., \& Chang, H. (2010). Living autoethnography: Connecting life and research [Editorial]. Journal of Research Practice, 6(1). Article E1. Retrieved from http://jirp.icaap.org/index.php/ irp/article/view/241/186

Ogbu, (1993). Differences in cultural frame of reference. International Journal of Behavioral Development, 16(3), 483-506.

Okonofua, B. A. (2013). "I am Blacker than you": Theorizing conflict between African immigrants and African Americans in the United States. SAGE Open, 3(3). doi :10.1177/2158244013499162

Perry, M. (2002). U.S. Black immigration, race, and racialization: An annotated bibliography. The Black Diaspora Consortium/Rockefeller Foundation: University of Texas, Austin.

Richardson,T., Bethea, A., Hayling, C.C \& Williams-Taylor, C. (2010). African and Afro-Caribbean American identity development: Theory and practice 
implications. In J. Ponterotto (Ed.), Handbook of multicultural counseling (pp. 227-240). Thousand Oaks, CA: Sage

Reed-Danahay, D. (Ed.). (1997). Auto/ethnography: Rewriting the self and the social, explorations in anthropology. Oxford, UK: Berg.

Shapiro, J., Sewell, T., \& DuCette, J. (1995), Reframing diversity in education. Lanham, MD: Technomic Publishing Co.

Tatum, B. (1992). Talking about race, learning about racism: The application of racial identity development theory in the classroom. Harvard Educational Review, 62(1), 1-25.

Tikly, L. (1999). Postcolonialism and comparative education. International Review of Education, 45(5/6), 603-621.

Warner, O. (2012). Black in America too: Afro-Caribbean immigrants. Social \& Economic Studies, 61(4), 69-103.

Waters, M. C. (1999). Black identities, West Indian immigrant dreams and American realities. New York, NY: Harvard University Press.

Wilson, E. S. (2009). What it means to become a United States American: AfroCaribbean immigrants' constructions of American citizenship and experience of cultural transition. Journal of Ethnographic \& Qualitative Research, 3(3), 196-204.

Worrell, F. C. (2012). Forty years of Cross's Nigrescence theory: From stages to profiles, from African Americans to all Americans. In: Sullivan, J.M, Esmail, A.M (Eds.). African American identity: Racial and cultural dimensions of the Black experience (pp. 3-28). Lanham, MD: Lexington Books.

\section{Author Contact}

Kathy-ann Hernandez: khernand@eastern.edu

Eastern University, 1300 Eagle Rd., St. David's, PA 19087

Kayon K. Murray-Johnsom: kkm56@txstate.edu

Texas State University, 1601 University Dr., San Marcos, TX 78666 